\title{
The Rights of Land-Locked States in the International Law: The Role of Bilateral/Multilateral Agreements
}

\author{
Endalcachew Bayeh \\ Department of Civics and Ethical Studies, College of Social Sciences and Humanities, Ambo University, Ambo, Ethiopia
}

Email address:

endbayeh@gmail.com

To cite this article:

Endalcachew Bayeh. The Rights of Land-Locked States Under the International Law: The Role of Bilateral/Multilateral Agreements. Social Sciences. Vol. 4, No. 2, 2015, pp. 27-30. doi: 10.11648/j.ss.20150402.12

\begin{abstract}
The United Nations Convention on the Law of the Sea 1982 provided rights for land-locked states on the sea. More importantly, the convention provided them with the right of access to and from the seas and freedom of transit. However, the law makes such rights subject to the agreements to be made by land-locked and transit states. This, in turn, depends on the prevailing relations between the concerned states. If they are not in a smooth relation, the transit states may not be willing to negotiate and thereby put impediments on the land-locked states' free transit. The political will and commitment of transit states highly conditioned the rights of land-locked states. The denial of free transit, in turn, affects the rights of land-locked states on the different maritime regimes. Land-locked states have no absolute right of access to and from the seas and freedom of transit. Hence, the study concludes that to give practical effect to those rights, negotiating bilateral and multilateral agreements with the transit states has a crucial and irreplaceable role.
\end{abstract}

Keywords: Land-Locked States, Transit States, Coastal States, Convention, Agreement, Seas

\section{Introduction}

The seas cover more than $70 \%$ of the surface of the globe (Malanczuk, 1997). The seas have historically performed two important functions: first, as a medium of communication, and secondly as a vast reservoir of living and non-living resources (Shaw, 2008). These functions have induced the development of legal rules governing the seas. Among these, currently, the most relevant one is United Nations Convention on the Law of the Sea 1982 (herein after the Convention). The central objective of the study is to examine the rights conferred on land-locked sates by the Convention and the role of negotiating bilateral and multilateral agreements in the practical realization of those rights. The study is not a country-based analysis or not intended to delve into a single land-locked state instead it envisaged the condition of all land-locked states of the world in general. To this end, the study looked into the relevant legal provisions, mainly in the United Nations Convention on the Law of the Sea 1982, and other pertinent secondary sources/literatures analyzing the issue from different angles.

\section{Conceptualizing Landlocked States}

Defining the term land-locked state is not problematic. The definitions given by different bodies are by and large similar. For the sake of this study, the researcher resorted to the definition given by United Nations Convention on the Law of the Sea 1982, which is the central reference of this study. Accordingly, article 124 (1(a)) of the Convention defines the term land-locked State as 'a State which has no sea-coast'. Putting it simply, land-locked state means a state which has no sea-coast; instead, it depends on its neighbouring state (s) to have access to the sea. In other words, land-locked state relays on transit state which is 'a state with or without a seacoast, situated between a land-locked state and the sea, through whose territory traffic in transit passes (Article 124 $(1, b)$ of the Convention). Thus, land-locked states are those states which get access to the sea through the territory of their neighbouring states known as transit states. They pass persons, baggage, goods, and other freights through the land of transit states. For instance, India and Bangladesh are transit states for Nepal, Senegal is transit state for Mali, Argentina together with other South American states is transit state for Bolivia (Rana, 2010), and Djibouti is also the most important transit state to Ethiopia. Thirty-seven states of the 
world are land-locked states (Uprety, 2003). They enjoy access to the sea via their neighbours. The rights they are endowed with vis- a-vis- their transit states and generally on the seas are outlined herein under.

\section{The Rights of Land-Locked States}

\subsection{Access Rights}

In this regard, it is compelling to look into Article 125 of the Convention, which plainly articulates the right of access to and from the sea and freedom of transit of land-locked states. This article is fully stated herein under to give a clear understanding of the issue in question and thereby requiring no further elaboration as to the rights embodied.

Article 125: Right of access to and from the sea and freedom of transit

1. Land-locked States shall have the right of access to and from the sea for the purpose of exercising the rights provided for in this Convention including those relating to the freedom of the high seas and the common heritage of mankind. To this end, land-locked States shall enjoy freedom of transit through the territory of transit States by all means of transport.

2. The terms and modalities for exercising freedom of transit shall be agreed between the land-locked States and transit States concerned through bilateral, sub regional or regional agreements.

3. Transit States, in the exercise of their full sovereignty over their territory, shall have the right to take all measures necessary to ensure that the rights and facilities provided for in this Part for land-locked States shall in no way infringe their legitimate interests.

As can be observed from the above provision, land-locked states have the right of access to and from the sea and freedom of transit to enjoy rights conferred on them by the convention, which will be discussed later. Their right of access to and from the sea as well as freedom of transit has also been reaffirmed by UN GA Res. 46/212 of 20 December 1991(Malanczuk, 1997). Putting it simply, land-locked states are legally given with a right to access the sea. What else rights are given to land-locked states? This is the topic of discussion herein under.

\subsection{The Rights of Land-Locked States across Maritime Zones}

To better understand the rights of land-locked states on the seas, it is worth looking their rights on the different maritime zones. Accordingly, the following are maritime zones where land-locked states are conferred with several rights to exercise.

Territorial sea: It extends up to 12 nautical miles, measured from baselines (Article 3). Subject to the Convention, ships of all States, whether coastal or landlocked, enjoy the right of innocent passage through the territorial sea (Article 17) and freedom of navigation in the waters beyond the territorial sea (Article 38 (1)). Hence, land-locked states have the right of innocent passage, passage which is "not prejudicial to the peace, good order or security of the coastal state" (article 19 (1)).

Exclusive economic zone: Article 57 extends exclusive economic zone up to 200 nautical miles from the baselines. Article 58 (1) provides:

In the exclusive economic zone, all States, whether coastal or land-locked, enjoy, subject to the relevant provisions of this Convention, the freedoms referred to in article 87 of navigation and overflight and of the laying of submarine cables and pipelines, and other internationally lawful uses of the sea related to these freedoms, such as those associated with the operation of ships, aircraft and submarine cables and pipelines, and compatible with the other provisions of this Convention.

Article 69 (1) of the convention also provides that "landlocked States shall have the right to participate, on an equitable basis, in the exploitation of an appropriate part of the surplus of the living resources of the exclusive economic zones of coastal States".

High seas: As per article 86 of the convention high seas means "all parts of the sea that are not included in the exclusive economic zone, in the territorial sea or in the internal waters of a State, or in the archipelagic waters of an archipelagic State". Like other maritime zones, the high seas are a regime where land-locked states are allowed to exercise considerable rights. The high seas are beyond the national jurisdiction of any state. Article 89 of the convention underscored that no state can claim sovereignty over the high seas. Article 87 (1) also affirms that, "the high seas are open to all States, whether coastal or land-locked". Following this premise, the convention under the same provision provided for all states:

(a) freedom of navigation; (b) freedom of overflight; (c) freedom to lay submarine cables and pipelines, subject to Part VI; (d) freedom to construct artificial islands and other installations permitted under international law, subject to Part VI; (e) freedom of fishing, subject to the conditions laid down in section 2; (f) freedom of scientific research, subject to Parts VI and XIII.

Thus, it is evident that land-locked states are conferred with significant rights on the high seas equally with coastal states. Article 90 of the same further allows them to equally sail ships flying their flags on the high seas as coastal states. After all, the high seas are maritime zone where no exclusive jurisdiction of any state can be claimed or exercised.

The Area/ Seabed regime: Article 136 of the convention states that the area and its resources are the common heritage of mankind; where no state can claim or exercise sovereignty or sovereign rights (Article 137 (1)). More importantly, article 148 of the convention tends to promote the effective participation of land-locked states in the activities of the area having due regard to their special need. 


\section{The Importance of Negotiating Bilateral and Multilateral Agreements}

To enjoy all those rights mentioned above, land-locked states need to make agreement with the transit states. Securing access to the sea is the backbone of enjoyment of the entire rights on the sea. Though land-locked states are given with legal right of access to and from the sea and freedom of transit under article 125 (1), such rights are put along with significant practical restrictions. Accordingly, article 125 (2) states that 'the terms and modalities for exercising freedom of transit shall be agreed between the land-locked States and transit States concerned through bilateral, sub regional or regional agreements.' Even though one cannot deny the relevance of international law of the sea to the land-locked states' overall rights on the sea, the fact remains that the very enjoyment of those rights is contingent up on the negotiation to be made between land-locked and transit states. This is clearly articulated by Shaw (2008) that "it will thus be seen that there is no absolute right of transit, but rather that transit depends upon arrangements to be made between the landlocked and transit states. Nevertheless, the affirmation of a right of access to the sea coast is an important step in assisting landlocked states." Likewise, Diba (2014) also asserts that the right provided under Article 125 (1) seems not an absolute right and it should be considered along with sub article 2 and 3 of the same article. Article 125 (3) states that 'transit States, in the exercise of their full sovereignty over their territory, shall have the right to take all measures necessary to ensure that the rights and facilities provided for in this Part for land-locked States shall in no way infringe their legitimate interests.' Following this, it is also argued that the convention does not put a commitment on the transit states to refrain from creating constraints for landlocked states as sub article 3 gives complete rights to the transit states to take all measures necessary to ensure that the transit of land-locked states in no way contravenes their legitimate interests, though whether it is possible to totally stop passage or on certain occasions is not clear (ibid). Hence, the legal, administrative and political adjustments in the neighbouring states can be hindrances to the land-locked states' access rights under the guise of legitimate interest (Uprety, 2003). This shows the fact that easy and free access to and from the sea falls under the mercy of the concerned states' negotiations.

The importance of the seas is universally known. Thanks for rapid technological advancement the value of the seas has increasingly been recognized and claimed. They serve as a means of communication, a source of food and ample treasure of unexploited resources (ibid). These and other sea related benefits are better if enjoyed by all states of the world including coastal and non-coastal states, albeit the degree may differ. This fact is underscored by the international law of the sea through providing land-locked states rights to enjoy benefits on the seas. However, at the center of the issue is the importance of land-locked states' agreement with costal/transit states. Land-locked states are so dependent on bilateral agreements pertaining to transit traffic (UN, 2007). One notable example in this regard is Ethiopia-Djibouti relations. Currently, Ethiopia is dependent on the transit routes of Djibouti to access the sea (ibid) once it has become land-locked state following the secession of Eritrea and, more importantly, the occurrence of Ethio-Eritrean war (1998-2000). The bilateral agreements of Ethiopia and Djibouti helped Ethiopia to enjoy the port of Djibouti and other related services. Hence, the relation of these two countries, though not the only, is best example of the relevance of agreements/negotiations for land-locked states to access the sea and enjoy benefits on the sea.

The fact that land-locked states are lag behind in their overall development compared to their neighbouring coastal states (Faye et al., 2004) shows their dependence on transit states for all things they transport to the sea. It is rightly outlined that, the reason why land-locked states are much worse than coastal states in their economic and human development indicators is their dependence on other countries' transit routes to access overseas markets (ibid). This, in turn, is dependent on land-locked states' political relations with neighbours. Land-locked states are too much dependent on their political relations with the transit states in exercising their rights. Transit states can put impediments if they are in conflict (military or diplomatic) with land-locked states (ibid). Even though there is a legal basis for landlocked states to access to and from the sea through transit states as outlined in Article 125(1) of the Convention, practically, this right of access must be based on agreement with the transit neighbour (Article 125(2) and (3)) and is contingent up on the prevailing relationship between the land-locked and transit states (Faye et al., 2004; Snow et al, 2003). Despite the fact that land-locked states are given with a right of access legally, the still worrying issue is such a right is conditioned by the need for the transit states to grant such a right (Snow et al, 2003). The willingness of transit states matters. In this connection, it is worth mentioning Ethiopia's denial of access to the port of Assab (where 75\% of Ethiopian trade passed through duty-free until 1997) following its conflict with Eritrea (Faye et al., 2004; Snow et al, 2003). The transit states may not show a political will to conclude negotiations thereby affecting the land-locked states' right of access to and from the sea (Government of Mongolia, 2007). In this regard, Gevorgyan (2011) rightly noted that:

\section{Existing freedom of transit for LLDCs as embodied in ........ the UN Law of the Sea Convention has for too long tended to be notional rather than real. LLDCs have had to rely on the political good will of transit States in multilateral and bilateral negotiations for agreements to give practical effect to those rights.}

As a result of this observed problem, Government of Mongolia (2007) goes to recommend that regional cooperation among landlocked and transit states through joint initiatives such as development of transit corridors is clearly an important lesson for LLDCs. 
At the top of all, article 69(1) of the convention provides the right of landlocked states to participate in the exploitation of the surplus of living resources in the exclusive economic zone on equitable manner. However, here again the terms and modalities of such participation are to be made by the concerning states through bilateral, sub regional or regional agreements (sub 2 of the same article). This shows that, even though the state secures free transit, it needs to have a sort of agreement with the costal state of an exclusive economic zone to exploit surplus of living resources.

Therefore, one can safely say that negotiations and agreements have pivotal role so as to fully enjoy the rights of land-locked states, thereby filling gaps in the substantive rights of land-locked states in the international law of the sea. Putting it differently, negotiating bilateral and multilateral agreements with concerned states has very significant role in accessing the seas as well as enjoying the entire rights on the seas. This is because, in the absence of agreement, the possibility of compelling transit states to give passage for land-locked states seems nonexistent as can be deduced from the relevant legal provisions.

\section{Concluding Remarks}

Thirty-seven states of the world are land-locked states. They enjoy rights on the sea by passing through their transit states. United Nations Convention on the Law of the Sea 1982 has conferred land-locked states different rights across different maritime zones. Besides, the convention also provided land-locked states rights of access to and from the seas and freedom of transit. However, the law conditioned their right of access to and from the seas and freedom of transit by the agreements to be made by states concerned. Those rights are not absolute in a sense that they are contingent upon the agreement between the land-locked and costal states. In a nutshell, the practical implementation of land-locked states' rights depends on the concerned states' relations, agreements, and/or the political will of transit states.

\section{References}

[1] Diba, Bahman Aghai (2014), "Iran and Landlocked States", [Online] Available at http://www.payvand.com/news/14/dec/1111.html
[2] Faye, Michael L., Mcarthur, John W., Sachs, Jeffrey D. and Snow, Thomas (2004) "The Challenges Facing Landlocked Developing Countries", Journal of Human Development, Vol. 5, No. 1, pp. 31-68

[3] Gevorgyan, Anna S (2011) "The Transit Regime for Landlocked States: International Law and Development Perspectives", A Master's Essay, American University of Armenia, Armenia

[4] Government of Mongolia (2007) "Trade, Trade Facilitation and Transit Transport Issues for Landlocked Developing Countries Executive Summary", Available at: http://unohrlls.org/UserFiles/File/LLDC\%20Documents/MTR /Executive\%20summary.pdf

[5] Malanczuk, Peter (1997) Akehurst's Modern Introduction to International Law, Seventh edition, New York: Routledge

[6] Rana, Ramesh Kumar (2010) "Right of access of land-locked state to the sea bythe example of bilateral agreement between land-locked state- Nepal and portstate - India", Master's Thesis, University of Tromsø

[7] Shaw, Malcolm N. (2008) International Law, Sixth edition, New York: Cambridge University Press.

[8] Snow, Thomas, Faye, Michael, McArthur, John and Sachs, Jeffrey (2003) "Country case studies on the challenges facing landlocked developing countries", OCCASIONAL PAPER, Background paper for HDR 2003

[9] UN (1982) "United Nations Convention on the Law of the Sea 1982", Available at: http://www.un.org/depts/los/convention_agreements/texts/uncl os/unclos_e.pdf

[10] (2007) "Regional cooperation in transit transport: Solutions for landlocked and transit developing countries", Trade and Development Board Commission on Enterprise, Business Facilitation and Development Expert meeting on regional cooperation in transit transport: Solutions for landlocked and transit developing countries, Geneva, 27-28 September 2007

[11] Uprety, Kishor (2003) "From Barcelona to Montego Bay and Thereafter: A Search for Landlocked States' Rights to Trade through Access to the Sea -A Retrospective Review" Singapore Journal of International \& Comparative Law, (2003) 7. Pp. 201-235 